\title{
DÜBLIN
}

Technological University Dublin

ARROW@TU Dublin

\section{Brewer's Spent Grain as a Functional Ingredient for Breadsticks}

Anastasia Ktenioudaki

Teagasc Food Research Centre, anastasia.ktenioudaki@teagasc.ie

Valérie Chaurin

Teagasc Food Reserach Centre, chaurin_valerie@yahoo.fr

Sofia Reis

Technological University Dublin, sofiafreis@gmail.com

See next page for additional authors

Follow this and additional works at: https://arrow.tudublin.ie/schfsehart

Part of the Food Processing Commons

\section{Recommended Citation}

Ktenioudaki, A., Chaurin, V., Reis, S.F., Gallagher, E. (2012). Brewer's spent grain as a functional ingredient for breadsticks. International Journal of Food Science \& Technology, 47, 1765-1771. doi:10.1111/ j.1365-2621.2012.03032.x

This Article is brought to you for free and open access by the School of Food Science and Environmental Health at ARROW@TU Dublin. It has been accepted for inclusion in Articles by an authorized administrator of ARROW@TU Dublin. For more information, please contact arrow.admin@tudublin.ie, aisling.coyne@tudublin.ie, gerard.connolly@tudublin.ie.

Funder: Irish Department of Agriculture, Food and the Marine, Food Institutional Research Measure (FIRM)

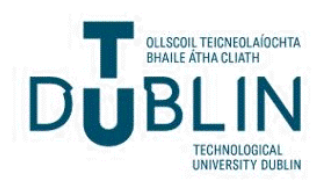


Authors

Anastasia Ktenioudaki, Valérie Chaurin, Sofia Reis, and Eimear Gallagher

This article is available at ARROW@TU Dublin: https://arrow.tudublin.ie/schfsehart/96 


\title{
Original article
}

\section{Brewer's spent grain as a functional ingredient for breadsticks}

\author{
Anastasia Ktenioudaki, ${ }^{1}$ * Valérie Chaurin, ${ }^{2}$ Sofia F. Reis $^{3}$ \& Eimear Gallagher ${ }^{1}$ \\ 1 Food Chemistry and Technology Department, Teagasc Food Research Centre, Ashtown, Dublin 15, Ireland \\ 2 Food Chemistry and Technology Department, Teagasc Food Research Centre, Moorepark, Cork, Ireland \\ 3 School of Food Science and Environmental Health, College of Sciences and Health, Dublin Institute of Technology, Cathal Brugha St., Dublin 1, \\ Ireland
}

(Received 21 November 2011; Accepted in revised form 4 March 2012)

\begin{abstract}
Summary
Brewer's spent grain (BSG) was evaluated for its potential as a functional baking ingredient. Scanning electron microscopy (SEM) was used to examine the microstructure of BSG and wheat flours. Baked snacks (breadsticks) were prepared using 15\%,25\% and 35\% BSG and evaluated for their baking quality and fibre and protein content (over a period of 3 months). The addition of BSG altered the baking characteristics of the breadsticks by affecting their structure and texture. The snacks appeared to lack in cellular structure and crispiness. However, they had quite a stable shelf-life, as changes in texture, moisture and $a_{\mathrm{w}}$ progressed at a low rate. Addition of $25 \%$ and $35 \%$ BSG significantly increased the protein content of the snacks, and addition of $15 \%$ BSG more than doubled the content of dietary fibre in the samples.
\end{abstract}

Keywords Baking, brewing, brewer's spent grain, dietary fibre, shelf-life, snacks.

\section{Introduction}

Brewer's spent grain (BSG) is generated during the production of beer and is considered to be an industrial by-product. It has mainly been used for animal feed, but there is currently strong argument for its use for human consumption (Stojceska \& Ainsworth, 2008) as it is rich in dietary fibre $(60-71 \%)$ (Ozturk et al., 2002; Mussatto et al., 2006) and has high protein content (Santos et al., 2003). The ingestion of $\mathrm{BSG}$, or products containing $\mathrm{BSG}$, can aid in the prevention of gastrointestinal disorders and cardiovascular diseases (Aman et al., 1994) and has been associated with increased faecal weight, accelerated transit time, increased cholesterol and fat excretion (Fastnaught, 2001).

The potential of BSG to enhance the nutritional value of cereal/bakery products has been studied in the past (Prentice \& Dappolonia, 1977; Dreese \& Hoseney, 1982); however, the topic has received renewed interest more recently (Ozturk et al., 2002; Ainsworth et al., 2007; Stojceska \& Ainsworth, 2008; Stojceska et al., 2008) because of the regained focus on the health benefits of dietary fibre and the investigation into novel low-cost sources of fibre. BSG has the potential to increase the fibre content, decrease the calorific content and increase the protein

*Correspondent: E-mail: ktenioudaki@hotmail.com content of food products (Hassona, 1993; Stojceska et al., 2008). Ainsworth et al. (2007) found that the addition of BSG in extruded snacks increased the fibre content of the snacks from $4.8 \%$ for the control sample $(0 \%$ BSG) to $19.8 \%$ for samples containing $30 \%$ BSG.

The incorporation of dietary fibre in bakery products has been studied over many years, and much literature is available in this area (Salmenkallio-Marttila et al., 2001; Kaack et al., 2006; Katina et al., 2006; Gomez et al., 2010). The main issues addressed are associated with the negative effects on the end-product quality such as appearance, texture and taste. As BSG is a material rich in dietary fibre, similar results are expected following its incorporation into bakery products. For example, Stojceska \& Ainsworth (2008) showed that the specific volume of breads decreased (from 3.22 to $2.06 \mathrm{~mL} \mathrm{~g}^{-1}$ ) and crumb firmness significantly increased with the addition of BSG in breads.

There is much interest in increasing the nutritional value of food (Arvanitoyannis \& Van HouwelingenKoukaliaroglou, 2005), where a particular focus is on redesigning healthier convenience foods and foods, which are consumed 'on the go'. At the same time, there is a significant growth for the market of savoury snacks. The European savoury snacks market grew by $3.8 \%$ in 2008 to reach a volume of 1.9 billion $\mathrm{kg}$, and it is forecast to have a volume of 2.3 billion $\mathrm{kg}$, an increase of $19.6 \%$ by 2013 (Datamonitor, 2009). Therefore, there 
is great potential for low-cost by-products such as BSG to be used as a functional ingredient in snack formulations.

The main objective of this study was to evaluate the potential of BSG as a high-fibre, high-protein ingredient for baked snacks. The microstructure of wheat and BSG flours was investigated using scanning electron microscopy (SEM), and the incorporation of BSG in breadstick formulation was evaluated in terms of baking quality and fibre and protein content of the products. The shelf-life of the breadsticks was also evaluated over a period of 3 months.

\section{Materials and methods}

\section{Materials}

Commercial wheat flour $[12.7 \%$ moisture, $13.1 \%$ protein, $0.5 \%$ fat, $0.9 \%$ ash, $74.4 \%$ total starch and $4.1 \%$ total dietary fibre (TDF)] was purchased locally (Odlums Bakers Flour, Odlum group, Alexandra road, Dublin, Ireland) and was used for this study. Dried brewer's spent grain $(5.6 \%$ moisture, $20.8 \%$ protein, $4.5 \%$ fat, $3.2 \%$ ash, $3.3 \%$ total starch and $60.5 \%$ TDF) was obtained from the micro-brewery establishment in University College Cork, Ireland. The BSG was milled using a Perten Laboratory Mill 3100 (Perten Instruments AB, Kungens Kurva, Sweden) to a particle size smaller than $355 \mu \mathrm{m}(59.5 \%$ of the BSG flour consisted of particles between 355 and $250 \mu \mathrm{m}$ ).

\section{Scanning electron microscopy}

The microstructure of wheat and BSG flours was visualised using SEM. The instrument was a Carl Zeiss Gemini Supra 40VP field emission SEM (Carl Zeiss SMT AG, Oberkochen, Germany). The samples for analysis were sprinkled onto double-sided adhesive carbon tape on aluminium SEM stubs, sputter-coated with platinum. The accelerating voltage used for the SEM was constant at $2 \mathrm{kV}$, while the magnification was varied from $50 \times$ to $5000 \times$. In this study, only images from $250 \times$ to $500 \times$ are shown.

\section{Breadsticks preparation}

Breadsticks were produced from flour blends containing 0 (control, $100 \%$ wheat flour), $15 \%, 25 \%$ and $35 \%$ of BSG (wheat flour replacement). Dough samples were prepared by mixing $1000 \mathrm{~g}$ flour, $20 \mathrm{~g}$ salt (table salt purchased locally), $20 \mathrm{~g}$ sugar (Blake's Ingredients, Dublin, Ireland), $10 \mathrm{~g}$ emulsified bread fat (Irish Bakels Ltd., Dublin, Ireland) and $25 \mathrm{~g}$ fresh yeast (Yeast Products, Dublin, Ireland) with water as per Farinograph readings in a Kenwood mixer. The Farinograph water absorptions were $61 \%, 68 \%, 72 \%$ and $73.5 \%$ for the control, $15 \%, 25 \%$ and $35 \%$, respectively, and the mixing times were 4, 4.5, 5 and $7 \mathrm{~min}$, respectively. After mixing, the dough rested for $40 \mathrm{~min}$ in a proofing cabinet $\left(35^{\circ} \mathrm{C}, 80 \% \mathrm{RH}\right)$ (Koma SDCC-1P/W; Koma Koeltechnische Industrie B.V., Roermond, the Netherlands) and was then sheeted to $3 \mathrm{~mm}$ thickness using a pastry dough sheeter (Rondo Doge Econom; RONDO Burgdorf AG, Switzerland). The breadsticks were cut into shape (7 cm length and $1.5 \mathrm{~cm}$ width), proofed for a further $15 \mathrm{~min}$ and baked for $35 \mathrm{~min}$ at $180^{\circ} \mathrm{C}$ in a deck oven (Compacta; Tom Chandley Ovens, Manchester, $\mathrm{UK})$.

The breadsticks were allowed to cool for $2 \mathrm{~h}$ and then placed in plastic bags. Ten breadsticks per flour blend were analysed over a period of 91 days (days 1, 4, 15, 29, 59, 70 and 91).

\section{Compositional analysis}

Moisture content of the breadsticks was measured according to the ICC method No. 110 (ICC, 1976) using a Brabender moisture oven (Brabender OHG, Duisberg, Germany). The test took place on each storage day. Ten samples were ground, and the results are the average of duplicate measurements.

Total starch was measured using the Megazyme Assay procedure (K-TSTA; Megazyme, Bray, Ireland) based on the AACC 76.13 and AOAC 996.11 methods.

Total dietary fibre analysis was conducted using the Fibertec System E (Foss Analytical, Slangerupgade, Denmark) as described in Alvarez-Jubete et al. (2009).

Protein content was determined as total nitrogen content by the Kjeldhal method $(\mathrm{N} \times 6.25)$ according to the AOAC method No. 920.87 (AOAC, 2000a).

Fat content was measured using a Soxhlet system. Extraction was carried out with $200 \mathrm{~mL}$ diethyl ether for $8 \mathrm{~h}$ at $60^{\circ} \mathrm{C}$.

Ash content was measured according to the AOAC method No 923.03 (AOAC, 2000b).

\section{Water activity}

Water activity $\left(a_{\mathrm{w}}\right)$ of all samples was measured using the $a_{\mathrm{w}}$ AquaLab meter (Decagon Devices Inc., Pullman, WA, USA). A small quantity (approximately $2 \mathrm{~g}$ ) of ground sample was placed in a disposable container and placed in the water activity metre. The $a_{\mathrm{w}}$ and the temperature were recorded. Duplicate measurements were taken for each sample.

\section{Volume}

The volume of the breadsticks was determined using a volume measurer (BVM-L370, TexVol Instruments, Viken, Sweden). The results are the average of ten samples and were measured on day 1 . 


\section{Texture analysis}

A snap test was used to evaluate the textural properties of the breadsticks and monitor any changes, which occurred during storage. The test was performed using a Texture Analyzer (TA-XT2i; Stable Microsystems, Surrey, UK), equipped with a $25-\mathrm{kg}$ load cell and a three-point bending rig (HDP/3PB). The two adjustable supports of the base plate were set $20 \mathrm{~mm}$ apart, and the sample was placed on top. The upper blade moved downwards at a speed of $5 \mathrm{~mm} \mathrm{~s}^{-1}$. The maximum force required breaking the sample and the distance at the point of break were recorded using the Texture Expert software version 1.22. Ten samples were measured from each blend, and the results were averaged. The test was performed on days 1, 4, 15, 29, 59, 70 and 91.

\section{Colour measurement}

Colour measurements were taken on ground samples using a Hunter Lab colorimeter (Hunter Lab, UltraScan $\mathrm{XE}$, Reston, VA, USA). $L^{*}, a^{*}$ and $b^{*}$ values were recorded. The tests took place on day 1 , and the results are the average of three measurements per sample.

\section{Statistical analysis}

All tests were replicated three times, and mean values and standard deviations were calculated. ANOvA oneway statistical analysis was carried out using Minitab (Minitab version 15.1.1.0.; Minitab Ltd., Coventry, UK) to determine significant differences in the measured properties and to carry out Pearson's correlation analysis between selected parameters.

\section{Results and discussion}

\section{Scanning electron microscopy}

Figure 1 shows SEM images of the wheat and BSG flour. Observations on the wheat flour identified brokenup endosperm tissue, spherical- and lentil-shaped starch granules and aggregates of protein matrix. Starch granules are seen to be embedded in the protein matrix. Similar observations for wheat flour have been reported before in the literature (Roman-Gutierrez et al., 2002; Gangadharappa et al., 2008).

The structure of the BSG flour appeared to consist mainly of husks, fibre filaments and remains of the endosperm. Starch granules are almost absent (Fig. 1c, d).
Figure 1 Scanning electron microscopy micrographs of $(a, b)$ : wheat flour, $(c, d)$ : brewer's spent grain flour.
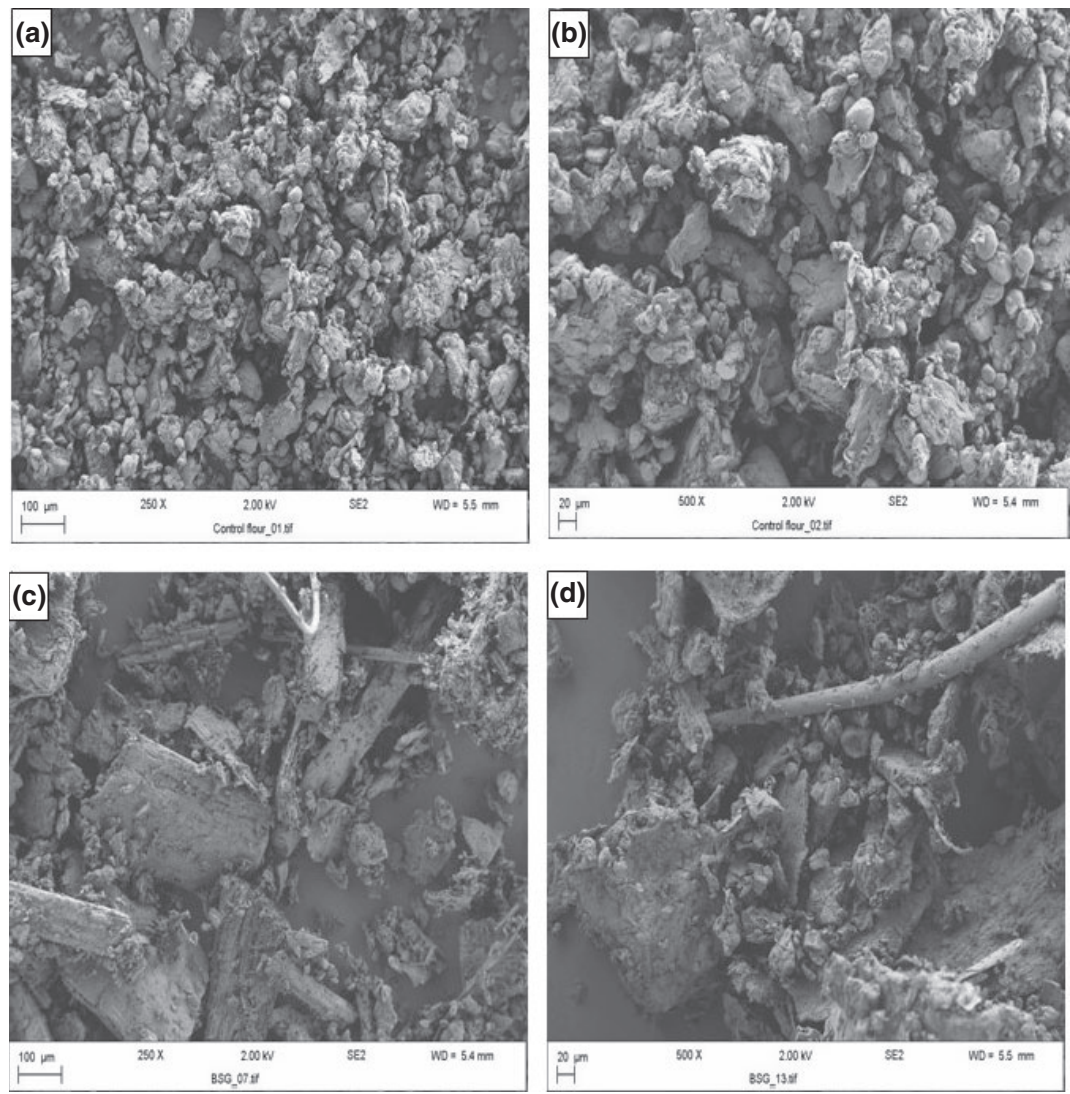
BSG usually contains the residues from malted barley or those from malted barley and other additional grains. BSG basically consists of the husk-pericarp-seed coat layers that covered the original barley grain and depending on the brewing practices used there could be residues of starchy endosperm and walls of empty aleurone cells (Mussatto et al., 2006).

\section{Compositional analysis}

The compositional analysis of the samples is shown in Table 1. Differences in moisture and ash contents between each blend were not significant. BSG addition increased both the fat and the protein content of the samples. Protein content increased from $14.3 \%$ (control) to $18.4 \%(35 \%$ BSG) and in comparison with the control was significantly higher for the samples with $25 \%$ and $35 \%$ BSG. Total starch decreased as the amount of BSG in the samples increased; this was because of the negligible content of starch in BSG. Figure 2 shows the content of dietary fibre in breadsticks. This increased significantly as the inclusions of BSG increased. The addition of $15 \%$ BSG more than doubled the content of dietary fibre in the samples.

Table 1 Compositional analysis of breadsticks containing different levels of BSG

\begin{tabular}{llllll}
\hline $\begin{array}{l}\text { BSG } \\
(\%)\end{array}$ & $\begin{array}{l}\text { Moisture } \\
(\%)\end{array}$ & Ash (\%) & Fat (\%) & Protein (\%) & $\begin{array}{l}\text { Total starch } \\
(\%)\end{array}$ \\
\hline 0 & $6.7 \pm 0.9^{\mathrm{a}}$ & $2.6 \pm 0.0^{\mathrm{a}}$ & $0.3 \pm 0.0^{\mathrm{a}}$ & $14.3 \pm 0.1^{\mathrm{a}}$ & $62.5 \pm 1.6^{\mathrm{c}}$ \\
15 & $6.5 \pm 2.2^{\mathrm{a}}$ & $3.3 \pm 0.6^{\mathrm{a}}$ & $0.8 \pm 0.0^{\mathrm{b}}$ & $15.2 \pm 0.3^{\mathrm{a}}$ & $54.5 \pm 2.8^{\mathrm{a}}$ \\
25 & $4.5 \pm 0.7^{\mathrm{a}}$ & $3.2 \pm 0.1^{\mathrm{a}}$ & $1.3 \pm 0.0^{\mathrm{c}}$ & $17.9 \pm 0.1^{\mathrm{b}}$ & $48.4 \pm 3.4^{\mathrm{a}, \mathrm{b}}$ \\
35 & $4.6 \pm 0.5^{\mathrm{a}}$ & $3.4 \pm 0.1^{\mathrm{a}}$ & $2.1 \pm 0.1^{\mathrm{d}}$ & $18.4 \pm 1.1^{\mathrm{b}}$ & $41.5 \pm 0.6^{\mathrm{a}}$ \\
\hline
\end{tabular}

BSG, Brewer's spent grain.

The results are expressed on dry weight basis.

Different superscripts in the same column denote statistically significant values $(P \leq 0.005)$

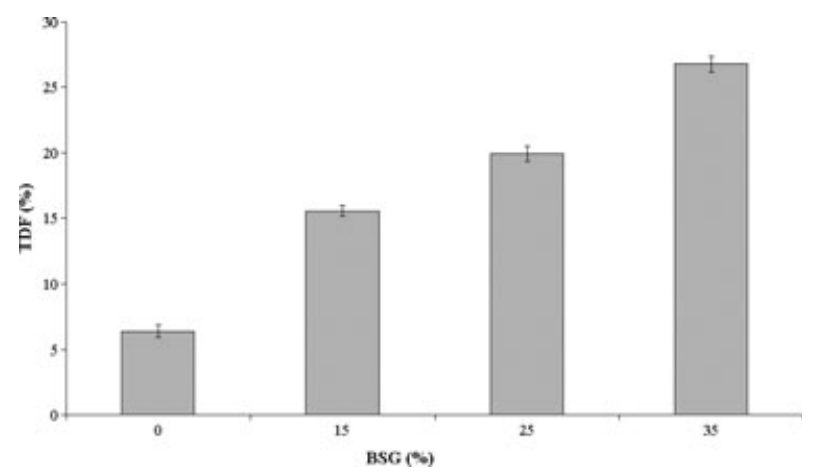

Figure 2 Total dietary fibre content of breadsticks containing different levels of brewer's spent grain.
Similarly, Stojceska \& Ainsworth (2008) found the levels of dietary fibre to vary between $6.3 \%$ and $11.5 \%$ for breads supplemented with BSG. Various levels of dietary fibre have been reported for baked products depending on the source of fibre. Cookies containing $15 \%$ extruded orange pulp had increased dietary fibre content of $11.25 \%$, in comparison with $2.1 \%$ for the control (Larrea et al., 2005).

\section{Baking quality}

The quality characteristics of the breadsticks that were significantly affected following addition of BSG are shown in Table 2. BSG is a dark material, and as with any addition of fibre in bakery products, the colour appeared significantly darker. The $L^{*}$ value indicates the lightness of the colour, and this parameter was significantly lower for all the BSG-containing breadsticks $(P \leq 0.005)$.

The volume decreased significantly for the breadsticks containing $15 \%, 25 \%$ and $35 \%$ BSG compared to the control; these results were highly correlated with the fibre content of the breadsticks $(r=-0.931)$. Figure 3 shows images of the structure of the breadsticks taken with the C-Cell Bread Imaging System (Calibre Control International Ltd, Warrington, UK). Breadsticks containing $25 \%$ and $35 \%$ BSG appear to be flat and without the typical cellular structure of yeasted, baked products. This is a direct result of the addition of dietary fibre, and as it has been shown previously by Stojceska \& Ainsworth (2008), BSG is a rich in fibre material, which affects the rheological properties of dough and also crumb structure and aeration properties of wheat breads. Similar results were observed by Wang et al. (2002), who reported a decrease in bread loaf volume when carob, pea and inulin were added.

The texture of the breadsticks as measured during a snap test relates to properties such as hardness and fracturability. The control sample was significantly harder than the BSG-containing samples $(P \leq 0.005)$. Generally, the addition of BSG and other fibrous ingredients to bread has shown an increase in the

Table 2 Baking characteristics of breadsticks containing different levels BSG

\begin{tabular}{lllll}
\hline BSG (\%) & $\begin{array}{l}\text { Volume } \\
(\mathbf{m L})\end{array}$ & $\begin{array}{l}\text { Hardness } \\
(\mathbf{N})\end{array}$ & $\begin{array}{l}\text { Fracturability } \\
(\mathbf{m m})\end{array}$ & \multicolumn{1}{l}{$\boldsymbol{L}^{*}$} \\
\hline 0 & $10.5 \pm 0.5^{\mathrm{c}}$ & $71.4 \pm 7.5^{\mathrm{b}}$ & $1.1 \pm 0.3^{\mathrm{b}}$ & $61.0 \pm 3.7^{\mathrm{b}}$ \\
15 & $6.5 \pm 0.6^{\mathrm{b}}$ & $46.6 \pm 3.9^{\mathrm{a}}$ & $0.2 \pm 0.1^{\mathrm{a}}$ & $46.5 \pm 2.4^{\mathrm{a}}$ \\
25 & $5.0 \pm 0.3^{\mathrm{a}}$ & $38.9 \pm 1.4^{\mathrm{a}}$ & $0.5 \pm 0.1^{\mathrm{a}}$ & $46.7 \pm 2.5^{\mathrm{a}}$ \\
35 & $5.0 \pm 0.1^{\mathrm{a}}$ & $35.4 \pm 3.0^{\mathrm{a}}$ & $0.5 \pm 0.1^{\mathrm{a}}$ & $43.9 \pm 0.6^{\mathrm{a}}$ \\
\hline
\end{tabular}

BSG, Brewer's spent grain.

Different superscripts in the same column denote statistically significant values $(P \leq 0.005)$. 


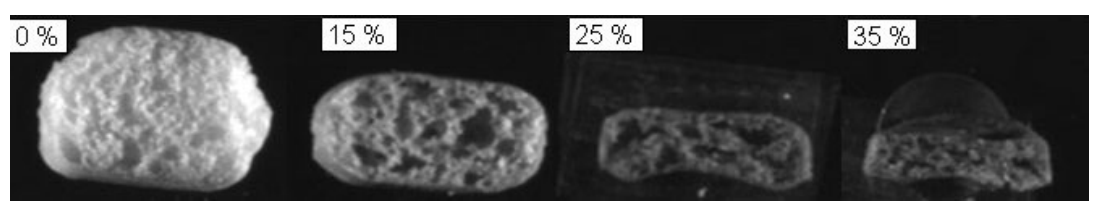

Figure 3 Crumb grain images of breadsticks containing different levels of brewer's spent grain.

hardness of the crumb (Stojceska \& Ainsworth, 2008). However, the higher force recorded during the snap test in the present trial is related to the crispiness of the sample. Control samples gave a jagged line during the test with more than one peak, which has been related to the degree of crispiness of a product (Vincent, 1998). Crispiness was decreased as the addition of BSG increased. This was because of the reduced volume and the lack of cellular structure in these when compared to the control. Loss of crispiness has been reported for cookies with added fibre such as wheat bran. Gujral et al. (2003) found that cookies with added wheat bran (up to 10\%) lost their crispiness and became leathery. Fibres from various sources (apple, lemon, wheat and wheat bran) were also found to alter the textural properties of wire cut cookies by increasing or decreasing the hardness of the cookies depending on the fibre source and the level added (Uysal et al., 2007).

\section{Shelf-life}

Breadsticks were stored for 91 days at room temperature, and moisture, water activity $\left(a_{\mathrm{w}}\right)$ and texture were assessed on days 1, 4, 15, 29, 59, 70 and 91. Moisture content increased slightly over this period, but the results did not indicate any significant differences (Results not shown).

Water activity is an important measure of a product's shelf-life. According to Katz \& Labuza (1981), water activity between 0.2 and 0.3 is optimum for dry samples, and physical changes begin when the $a_{\mathrm{w}}$ is between 0.35 and 0.5 , at which point loss of crispiness may occur. Changes in water activity over the 91-day storage period are shown in Fig. 4. Water activity ranged from 0.38 to 0.48 for the control samples during the 91 days. Water activity for newly baked samples (day 1) was 0.37 and began to increase after day 15 and again after day 70, reaching a peak of 0.45 at day 91 . The $a_{\mathrm{w}}$ of the samples containing 15\% BSG increased above 0.35 after the 29th day, whereas for the 25 and $35 \%$ BSG-containing samples, the $a_{\mathrm{w}}$ was between 0.22 and 0.30 until day 50; increases to $0.37-0.42$ were observed after that. The lower $a_{\mathrm{w}}$ in all BSG-containing samples can be attributed to the fact that the water was present in the bound form compared to the control samples, because of the increased fibre content (fibres are known to have high affinity for water and strongly bind the water available during the hydration-mixing stage).

The texture of the breadsticks was also monitored over the 91-day storage period. It was found that the hardness of the samples tended to decrease during storage (Fig. 5). However, the differences between the fresh samples (day 1) were quite small and insignificant in the case of those samples containing $25 \%$ and $35 \%$ BSG. The hardness of the control sample decreased from $73.4 \mathrm{~N}$ (day 1) to $46.7 \mathrm{~N}$ (day 91), and significant differences became apparent after day 50 of storage. Similarly, for the samples containing $15 \%$ BSG, the

Figure 4 Changes in water activity $\left(a_{\mathrm{w}}\right)$ of

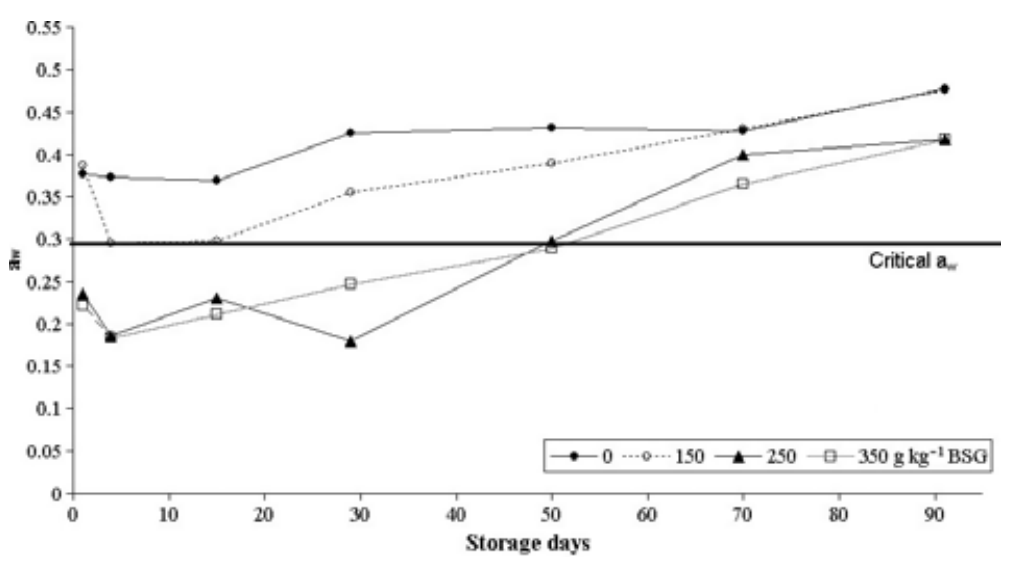

breadsticks over the 91-day storage period. 


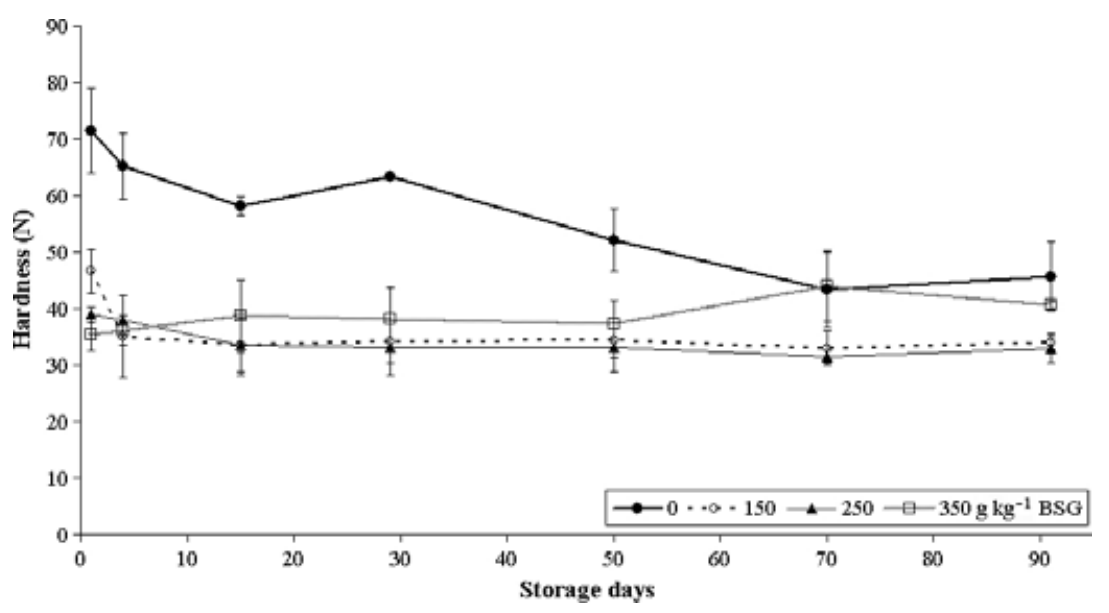

Figure 5 Hardness of breadsticks over the 91day storage period. hardness decreased significantly from $46.6 \mathrm{~N}$ (day 1) to $34.0 \mathrm{~N}$ (day 91).

Overall, all breadsticks were found to be quite stable during storage with significant changes in texture and $a_{\mathrm{w}}$ taking place generally only after day 50 . The critical point of $a_{\mathrm{w}}(0.35)$ after which physical state changes begin was exceeded after longer storage for the BSG samples than the control. However, any changes in texture for all samples progressed at a very low rate.

\section{Conclusion}

The incorporation of BSG in baked snacks such as breadsticks significantly increased their dietary fibre content. However, some baking properties were significantly affected. Breadsticks containing BSG were darker, less crispy and of lower baking volume, all of which are directly attributed to the high content of BSG in fibre. The shelf-life of the breadsticks was monitored, and it was found that the quality of the breadsticks was unchanged for up to approximately 50 days of storage. BSG has the potential to be used as a functional ingredient for bakery products, but more research is required to improve the quality and evaluate the consumer acceptance of these products. The investigation into bioprocessing techniques and enzymes that will improve the quality of baked snacks with BSG is currently underway, and the effects of BSG addition on dough microstructure and rheology are being explored.

\section{Acknowledgments}

The project was funded by the Irish Department of Agriculture, Food and the Marine under the Food Institutional Research Measure (FIRM). The authors would like to acknowledge the National Food Imaging Centre (Teagasc Moorepark, Co. Cork, Ireland) for access to the scanning electron microscope.

\section{References}

Ainsworth, P., Ibanoglu, S., Plunkett, A., Ibanoglu, E. \& Stojceska, V. (2007). Effect of brewers spent grain addition and screw speed on the selected physical and nutritional properties of an extruded snack. Journal of Food Engineering, 81, 702-709.

Alvarez-Jubete, L., Arendt, E.K. \& Gallagher, E. (2009). Nutritive value and chemical composition of pseudocereals as gluten-free ingredients. International Journal of Food Sciences and Nutrition, 60, $240-257$.

Aman, P., Zhang, J., Hallmans, G. \& Lundin, E. (1994). Excretion and degradation of dietary fiber constituents in ileostomy subjects consuming a low fiber diet with and without brewer's spent grain. Journal of Nutrition, 124, 359-363.

AOAC (2000a). AOAC Method No 920.87

AOAC (2000b). AOAC method No 923.03

Arvanitoyannis, I.S. \& Van Houwelingen-Koukaliaroglou, M. (2005). Functional foods: a survey of health claims, pros and cons, and current legislation. Critical Reviews in Food Science \& Nutrition, 45, 385-404.

Datamonitor (2009). Savoury snacks in Europe.

Dreese, P.C. \& Hoseney, R.C. (1982). Baking properties of the bran fraction from brewer's spent grains. Cereal Chemistry, 59, 89-91.

Fastnaught, C.E. (2001). Barley fiber. In: Handbook of Dietary Fiber (edited by S. Cho, M.L. Dreher \& S.S. Cho). Pp. 519-542. New York: Marcel Dekker.

Gangadharappa, G.H., Ramakrishna, R. \& Prabhasankar, P. (2008). Chemical and scanning electron microscopic studies of wheat wholemeal and its streams from roller flour mill. Journal of Food Engineering, 85, 366-371.

Gomez, M., Moraleja, A., Oliete, B., Ruiz, E. \& Caballero, P.A. (2010). Effect of fibre size on the quality of fibre-enriched layer cakes. LWT-Food Science and Technology, 43, 33-38.

Gujral, H.S., Mehta, S., Samra, I.S. \& Goyal, P. (2003). Effect of wheat bran, coarse wheat flour, and rice flour on the instrumental texture of cookies. International Journal of Food Properties, 6, 329340 .

Hassona, H.Z. (1993). High fibre bread containing brewer's spent grains and its effect on lipid metabolism in rats. Food/Nahrung, 37, $576-582$.

ICC (1976). ICC standard Method No. 110/1

Kaack, K., Pedersen, L., Laerke, H.N. \& Meyer, A. (2006). New potato fibre for improvement of texture and colour of wheat bread. European Food Research and Technology, 224, 199-207.

Katina, K., Salmenkallio-Marttila, M., Partanen, R., Forssell, P. \& Autio, K. (2006). Effects of sourdough and enzymes on staling of 
high-fibre wheat bread. LWT-Food Science and Technology, 39, 479491.

Katz, E.E. \& Labuza, T.P. (1981). Effect of water activity on the sensory crispness and mechanical deformation of snack foodproducts. Journal of Food Science, 46, 403-409.

Larrea, M.A., Chang, Y.K. \& Martinez-Bustos, F. (2005). Some functional properties of extruded orange pulp and its effect on the quality of cookies. LWT-Food Science and Technology, 38, 213220.

Mussatto, S.I., Dragone, G. \& Roberto, I.C. (2006). Brewers' spent grain: generation, characteristics and potential applications. Journal of Cereal Science, 43, 1-14.

Ozturk, S., Ozboy, O., Cavidoglu, I. \& Koksel, H. (2002). Effects of brewer's spent grain on the quality and dietary fibre content of cookies. Journal of the Institute of Brewing, 108, 23-27.

Prentice, N. \& Dappolonia, B.L. (1977). High-fibre bread containing brewer's spent grain. Cereal Chemistry, 54, 1084-1095.

Roman-Gutierrez, A.D., Guilbert, S. \& Cuq, B. (2002). Description of microstructural changes in wheat flour and flour components during hydration by using environmental scanning electron microscopy. LWT-Food Science and Technology, 35, 730-740.
Salmenkallio-Marttila, M., Katina, K. \& Autio, K. (2001). Effects of bran fermentation on quality and microstructure of high-fiber wheat bread. Cereal Chemistry, 78, 429-435.

Santos, M., Jiménez, J.J., Bartolomé, B., Gómez-Cordovés, C. \& del Nozal, M.J. (2003). Variability of brewer's spent grain within a brewery. Food Chemistry, 80, 17-21.

Stojceska, V. \& Ainsworth, P. (2008). The effect of different enzymes on the quality of high-fibre enriched brewer's spent grain breads. Food Chemistry, 110, 865-872.

Stojceska, V., Ainsworth, P., Plunkett, A. \& Ibanoglu, S. (2008). The recycling of brewer's processing by-product into ready-to-eat snacks using extrusion technology. Journal of Cereal Science, 47, 469-479.

Uysal, H., Bilgicli, N., Elgun, A., Ibanoglu, S., Herken, E.N. \& Demir, M.K. (2007). Effect of dietary fibre and xylanase enzyme addition on the selected properties of wire-cut cookies. Journal of Food Engineering, 78, 1074-1078.

Vincent, J.F.V. (1998). The quantification of crispness. Journal of the Science of Food and Agriculture, 78, 162-168.

Wang, J., Rosell, C.M. \& Benedito de Barber, C. (2002). Effect of the addition of different fibres on wheat dough performance and bread quality. Food Chemistry, 79, 221-226. 